\title{
Megaloblastic Anemia Due to Intrathecal Methotrexate
}

\author{
Intratekal Metotreksata Bağhl Megaloblastik Anemi \\ İrfan YAVAŞOĞLU, Gürhan KADIKÖYLÜ, Zahit BOLAMAN \\ Department of Hematology, Medical Faculty of Adnan Menderes University, Aydin
}

Submitted/ Başvuru tarihi: 24.10.2008 Accepted/Kabul tarihi: 18.11.2008

\begin{abstract}
We diagnosed to the patient as primary mediastinal CD20 positive diffuse large B-cell lymphoma two years ago. The patient received R-CHOP chemotherapy. Complete remission was obtained from chemotherapy. After 18 months, headache, nausea and vomiting occurred. Cranial magnetic resonance imaging showed mass lesions. Cranial radiotherapy was applied. Then intrathecal methotrexate (MTX) was administered at a dose of $12 \mathrm{mg}$ via lumbar puncture twice weekly for 6 weeks. Pancytopenia was detected after ten days of the discontinuation of intrathecal MTX. There were apparent megaloblastic changes on the bone marrow aspiration and biopsy. The biochemical parameters were folic acid $6.22 \mathrm{ng} / \mathrm{ml}$ ( $\mathrm{N}: 4.2-19.99)$ and cobalamin $803 \mathrm{pg} / \mathrm{ml}$ (N:197-866). The patient was treated with oral folic acid $5 \mathrm{mg} /$ day. Hematological parameters were hemoglobin $10.2 \mathrm{~g} /$ dl, platelet count $432000 / \mathrm{mm}^{3}$, and leukocyte count $5100 / \mathrm{mm}^{3}$ at the 14 th day. In conclusion, the patients treated with intrathecal MTX should be followed-up and folic acid prophylaxis may be considered.
\end{abstract}

Key words: Intrathecal methotrexate; lymphoma; megaloblastic anemia.
İki yıl once primer mediastinal CD20 pozitif yaygın büyük $B$ hücreli lenfoma tanısı koyduğumuz hasta, R-CHOP kemoterapisi aldı. Kemoterapiden sonra tam yanıt elde ettik. On sekiz ay sonra baş ağrısı, bulantı ve kusma şikayetleri başladı. Kraniyel magnetik görüntülemede kitle tespit edildi. Kraniyel radyoterapi uygulandı. Haftada 2 kez 6 hafta süreyle lumbar yolla $20 \mathrm{mg}$ intratekal methotrexate (MTX) verildi. Intratekal methotrexate kesildikten 10 gün sonra pansitopeni gelişti. Kemik iliği aspirasyon ve biyopsisinde megaloblastik değişiklikler gözlendi. Biyokimyasal değerlerinde folik asid $6.22 \mathrm{ng} / \mathrm{ml}$ (N:4.2-19.99) ve kobalamin $803 \mathrm{pg} /$ $\mathrm{ml}(\mathrm{N}: 197-866)$ idi. Oral folik asit $5 \mathrm{mg} / \mathrm{gün}$ başlandı. Ondördüncü günde hemoglobin $10.2 \mathrm{~g} /$ dl, platelet sayısı $432000 / \mathrm{mm}^{3}$ ve lökosit sayısı $5100 / \mathrm{mm}^{3}$ idi. Sonuç olarak intratekal methotrexate ile tedavi edilen hastalarda takip ve folik asit profilaksisi düşünülebilir.

Anahtar sözcükler: İntratekal metotreksat; lenfoma; megaloblastik anemi.
Megaloblastic anemia is usually caused by a deficiency
or defective absorption of either vitamin $\mathrm{B}_{12}$ or folic acid.
The most common cause is cobalamin or folic acid defi-
ciency. It usually occurred in advanced ages and is very
rare in young patients. But it reported in some patients
received with antineoplastic and immunosupressive drugs such as methotrexate, hydroxyurea, nucleoside analoges and aminopterin. Methotrexate (MTX), inhibits dihydrofolate reductase, is frequently used in the prevention of graft versus host disease (GVHD), the treatment of autoimmune diseases like rheumatoid arthritis, psoriasis, and hematological malignancies.

Correspondence (illetişim adresi): Dr. Irfan Yavaşoğlu. Adnan Menderes Üniversitesi Tıp Fakültesi Hematoloji Anabilim Dalı, 09100 Aydın. Tel: 0256 - 2120020 Fax (Faks): 0256 - 2146495 e-mail (e-posta):dr_yavas@yahoo.com

(c) Trakya Üniversitesi Tıp Fakültesi Dergisi. Ekin Tıbbi Yayıncıık tarafından basılımıstır. Her hakkı sakıdır.

(c) Medical Journal of Trakya University. Published by Ekin Medical Publishing. All rights reserved. 
Synthesis of purine and pyrimidine deteriorates upon the decrease of tetrahydrofolate. Deoxyribonucleic acid (DNA) synthesis is inhibited and cell death takes place. [1] When used intravenously, orally and intrathecal MTX can cause depletion of intracellular tetrahydrofolate, leading to megaloblastic anemia. ${ }^{[2]}$

Here we report that megaloblastic anemia is due to intratechal MTX in a patient with primary mediastinal CD20 positive diffuse large B-cell lymphoma and central nervous system (CNS) involvement.

\section{CASE REPORT}

Twenty-four-year old female suffered from chest pain and dyspnea two years ago. We diagnosed to the patient as primary mediastinal CD 20 positive diffuse large $\mathrm{B}$ cell lymphoma. There were pericardial and pleural involvements, while the bone marrow or CNS were normal. According to Ann Arbor Staging System, the patient was accepted in stage IV. R-CHOP chemotherapy (rituximab $375 \mathrm{mg} / \mathrm{m} 2$ for 1 day, vincristin 1.4 $\mathrm{mg} / \mathrm{m} 2$ for 1 day, cyclophosphamide $750 \mathrm{mg} / \mathrm{m} 2$ for 1 day, doxorubicin $50 \mathrm{mg} / \mathrm{m} 2$ for 1 day, and prednisone $100 \mathrm{mg} /$ day for 1-5 days) was given every 21 days for 8 courses. Complete remission was obtained from chemotherapy. After 18 months, headache, nausea and vomiting occurred. Cranial magnetic resonance imaging showed mass lesions on right frontal and left posterior parietal lobes (Fig. 1). Serological and histopathological assessments and whole blood counts of cerebrospinal fluid were normal. Intrathecal $20 \mathrm{mg}$ MTX twice a week for 6 weeks followed by cranial radiotherapy $46 \mathrm{~Gy}$ dose was applied to the patient. The patient did not receive any medication except of dexamethasone. After ten days of the discontinuation of treatment, fatigue occurred in the patient. Pallor and alopecia were detected. Hematological parameters were hemoglobin level $7.8 \mathrm{gr} / \mathrm{dl}$, hematocrit 23\%, platelet count $27000 / \mathrm{mm}^{3}$, leukocyte count $1000 / \mathrm{mm}^{3}$,

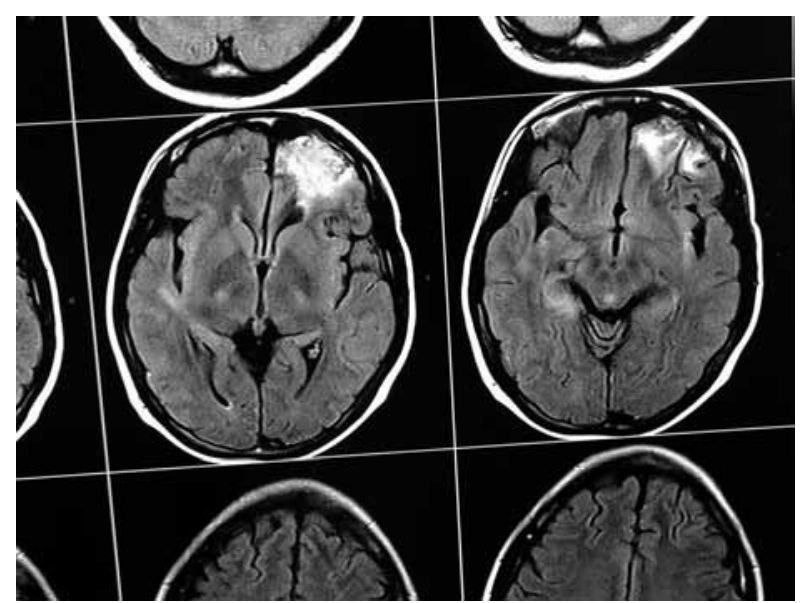

Fig. 1. Magnetic resonance imaging, mass lesions were detected in right frontal and left posterior parietal lobes.

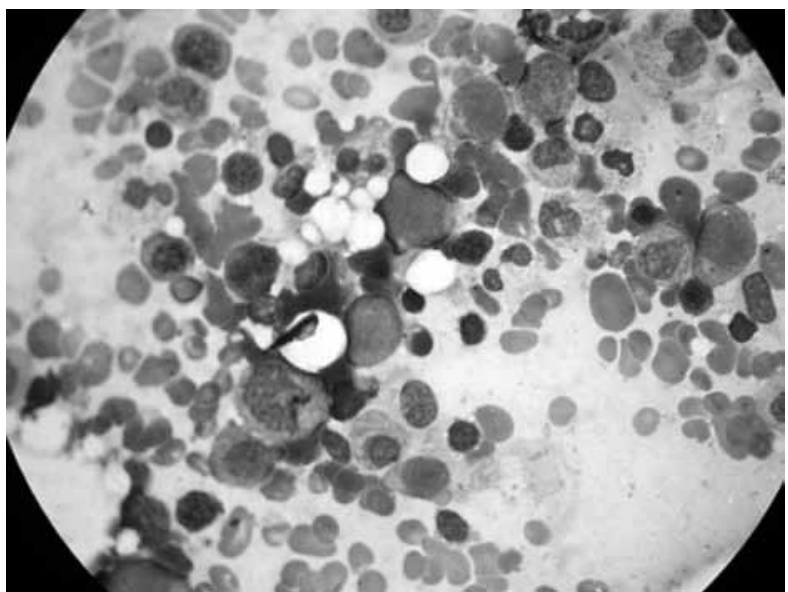

Fig. 2. On the bone marrow aspiration, there were erythroid hyperplasia (erythroid/ myeloid ratio: 1/1), significant megaloblastic changes in erythroid series, and arrested maturation in myeloid precursors.

neutrophil count $100 / \mathrm{mm}^{3}$, and mean corpuscular volume $97.5 \mathrm{fl}$, reticulocyte index $1 \%$. Iron parameters were serum iron $95 \mu \mathrm{g} / \mathrm{dl}$, total serum iron binding capacity $228 \mathrm{mg} / \mathrm{dl}$, percentage of iron $42 \%$, and ferritin $432 \mathrm{ng} / \mathrm{ml}$. Vitamin $\mathrm{B}_{12}$ and folic acid levels were $803 \mathrm{pg} / \mathrm{ml}(\mathrm{N}: 197-866)$ and $6.22 \mathrm{ng} / \mathrm{ml}(\mathrm{N}: 4.2-$ 19.99), respectively. Biochemical analyses were normal. On peripheral blood smear, decreased platelets and macrocytosis and aniso-poikilocytosis in erythrocytes were seen. On the bone marrow aspiration and biopsy, there were erythroid hyperplasia (erythroid/myeloid ratio:1/1), apparent megaloblastic changes in erythroid precursors, and arrested maturation in myeloid precursors (Fig. 2). We started $5 \mathrm{mg} /$ day folic acid to the patient. Reticulocyte crisis was seen at the 10th day of treatment and fatigue decreased. After 14 days, hematological parameters were hemoglobin level $10.2 \mathrm{~g} / \mathrm{dL}$, hematocrit $31.6 \%$, platelet count $432000 / \mathrm{mm}^{3}$, leukocyte count $5100 / \mathrm{mm}^{3}$, and neutrophil count $2500 / \mathrm{mm}^{3}$. Folic acid was given for 3 months. Then, we performed peripheral autologous stem cell transplantation to the patient. She is alive and followed-up.

\section{DISCUSSION}

Folic acid is essential for DNA synthesis. Folic acid antagonists such as aminopterin, methotrexate (MTX), pyrimethamine, trimethoprim, and triamterene may cause folic acid deficiency. ${ }^{[1]}$ Tetrahydrofolate level is decreased with in the cell by intravenous and oral MTX treatment. ${ }^{[2]}$ The efficacy and adverse effects of MTX such as myelosuppression, diarrhea, mucosal toxicity, and infection depend on dosage. Leukopenia, thrombocytopenia, pancytopenia and megaloblastic anemia are frequently seen in folic acid deficiency. Pretreatment levels of plasma or red cell folic acid were not useful in predicting of toxicity. ${ }^{[1-3]}$ 
High-dose (2 to $8 \mathrm{~g} / \mathrm{m} 2$ ) intravenous MTX is necessary for adequate cerebrospinal fluid penetration in the patients with CNS lymphoma. Moreover MTX is usually applied for CNS prophylaxis of leukemia and lymphoma. In the treatment of CNS involvement of nonHodgkin's lymphomas, intrathecal MTX administration is effective treatment modality. ${ }^{[4,5]}$ We used intrathecal $20 \mathrm{mg}$ MTX for CNS lymphoma. After ten days, fatigue and pancytopenia appeared in the patient. We diagnosed to the patient as megaloblastic anemia, because of pancytopenia, macrocytosis, megaloblastic changes in the peripheral blood and bone marrow. Serum folic acid level was normal. Erythrocyte folic acid levels were more valuable for the assessment of folic acid, but we could not examine. Hematological parameters were improved with folic acid treatment after 14 days. Use of the Naranjo ADR Probability Scale ${ }^{[6]}$ indicated a probable (numerical score $=7$ ) relationship between megaloblastic anemia and MTX therapy in this patient.

Sallah et al. ${ }^{[2]}$ reported megaloblastic anemia due to intrathecal MTX in three patients with acute leukemia. While folic acid level was normal in one patient, both serum and erythrocyte folic acid levels in 2 patients were low. All the patients were benefited from $5 \mathrm{mg} /$ day folic acid treatment. Bleyer et al. ${ }^{[7]}$ emphasized that tissue accumulation with intrathecal administration might be seen more than systemic MTX treatment in autopsy assessment of patients with leptomeningeal metastases of lung cancer. High MTX levels were detected in CNS as well as liver, kidney, lymph node, spleen, and bone. But MTX was not detected in myocardium, besides minimal accumulation in muscle tissues. So high bone levels may show bone marrow toxicity. ${ }^{[7]}$ In another study, plasma MTX levels with intrathecal application might be 20-30 times higher than systemic administration, despite being applied in similar doses. ${ }^{[8]}$ Cohen et al. ${ }^{[9]}$ was reported that pancytopenia might develop after $25 \mathrm{mg}$ single dose of intradermal MTX administration. Some authors showed that concomitant cranial irradiation and chronic intrathecal MTX reduced folic acid levels. ${ }^{[10]}$ We applied intrathecal MTX and cranial radiation to our patient. Cranial radiation may be an additional factor in the development of megaloblastic anemia in our patient.

In conclusion, megaloblastic anemia may appear after intrathecal MTX in patients with CNS lymphoma. So the patients treated with intrathecal MTX should be followed-up and folic acid prophylaxis may be considered.

\section{REFERENCES}

1. Wickramasinghe SN. Diagnosis of megaloblastic anaemias. Blood Rev 2006;20:299-318.

2. Sallah S, Hanrahan LR, Phillips DL. Intrathecal methotrexate-induced megaloblastic anemia in patients with acute leukemia. Arch Pathol Lab Med 1999;123:774-7.

3. Calvert H. Folate status and the safety profile of antifolates. Semin Oncol 2002;29(2 Suppl 5):3-7.

4. Cheung CW, Burton C, Smith P, Linch DC, Hoskin PJ, Ardeshna KM. Central nervous system chemoprophylaxis in non-Hodgkin lymphoma: current practice in the UK. Br J Haematol 2005;131:193-200.

5. Batchelor T, Loeffler JS. Primary CNS lymphoma. J Clin Oncol 2006;24:1281-8.

6. Naranjo CA, Busto U, Sellers EM, Sandor P, Ruiz I, Roberts EA, et al. A method for estimating the probability of adverse drug reactions. Clin Pharmacol Ther 1981;30:239-45.

7. Bleyer WA, Nelson JA, Kamen BA. Accumulation of methotrexate in systemic tissues after intrathecal administration. J Pediatr Hematol Oncol 1997;19:530-2.

8. Jacobs SA, Bleyer WA, Chabner BA, Johns DG. Letter: Altered plasma pharmacokinetics of methotrexate administered intrathecally. Lancet 1975;1:465-6.

9. Cohen PR, Schulze KE, Nelson BR. Pancytopenia after a single intradermal infiltration of methotrexate. J Drugs Dermatol 2005;4:648-51.

10. Kamen BA, Moulder JE, Kun LE, Ring BJ, Adams SM, Fish $\mathrm{BL}$, et al. Effects of single-dose and fractionated cranial irradiation on rat brain accumulation of methotrexate. Cancer Res 1984;44:5092-4. 